J. Perinat. Med. 10 (1982) 286

\title{
Reevaluation of the $\mathrm{pH}$, ferning and nile blue sulphate staining methods in pregnant women with premature rupture of the fetal membranes
}

\author{
I. G. Gorodeski, L. Haimovitz, C. M. Bahari
}

Department of Obstetrics and Gynecology "B", Meir Hospital, Sapir Medical Center, Kfar Saba, Israel

\section{Introduction}

Premature rupture of the fetal membranes (PRM) may present a variety of problems to the obstetrician, not the least of which is its diagnosis [10]. Nile blue sulphate (NBS) staining, determination of $\mathrm{pH}$ values and fern (arborization) test are the most often used diagnostic methods because they are simple, noninvasive, harmless, inexpensive and can be performed at the bedside. Some authors agree that these tests have high inaccuracy rates $[5,14]$. The purpose of the present study was to evaluate prospectively the accuracy of these methods in the diagnosis of prolonged PRM.

\section{Material and methods}

\subsection{Composition of the groups}

The women for the present study were arbitrarily selected from among those who were examined in the department or ambulatory care clinic. Some were hospitalized in the department due to causes not related to this study. None of the women were in active labor, and informed consent was obtained from all participants. All had a pelvic examination done including inspection of the cervix. The study protocol included a control group and a test group as follows:

\section{Curriculum vitae}

I. G. GORODESKI was born in Poland in 1948 and emigrated to Israel in 1950. In 1972 he was gratuated from the Sackler Medical School in the University of Tel Aviv and received the MD degree. During the years 19731977 he served in the IDF as a medical officer. In 1977 he started to spe-

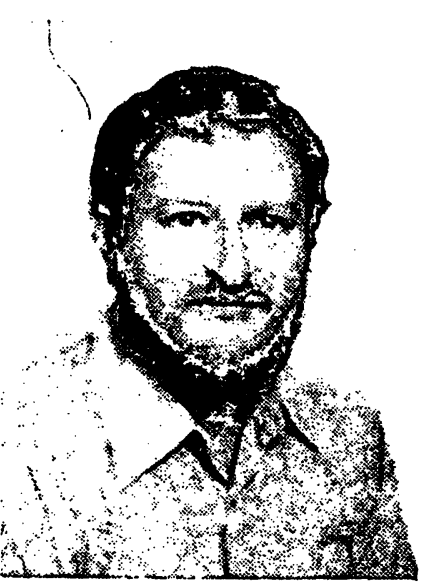
cialize in Obstetrics and Gynecology in the Department of Obstetrics and Gynecology, Beilinson Medical Center, and later in the Department of Obstetrics and Gynecology "B", Meir Hospital, Sapir Medical Center. In 1981 he received a Diploma from the Tel Aviv University Postgraduate Medical School. Currently he is doing a fellowship in Endocrinology in the Sheba Medical Center.

\subsubsection{Control group (3 subgroups):}

Subgroup A: women between 35-42 weeks gestation with intact membranes, who were examined 3 times: At their admission (time 0), 1-12 hours, and 13-24 hours after their admission.

Subgroup B: women between 35-42 weeks gestation with ruptured membranes. Some of them were admitted with a history of ruptured membranes which was confirmed by the atten- 
ding physician, and in others amniotomy was deliberately performed to induce or enhance labor. Each of the women was examined only once and was cathegorized into one of the following groups, according to the length of her latent period: $0-1,2-4,5-12,13-24$, or longer than 24 hours.

Subgroup C: women between 35-42weeks gestation with ruptured membranes. All were admitted with a history of ruptured membranes which was confirmed by the attending physician. Each woman in this subgroup was due to be examined 5 times according to the following schedule: $0-1,2-4,5-12,13-24$, or more than 24 hours after rupture of the membranes.

\subsubsection{Test group}

This group was composed of women with 36-42 weeks gestation who presented with a history of ruptured membranes, but in none of whom could the diagnosis be established with certainty. After their admission and examination, the patients were hospitalized. If clinically unequivocal rupture of the membranes was found to occur at any time between the initial investigation and delivery, the patient was classified as having had intact membranes at the time of the initial investigation. However, if during this period of surveillance the actual rupturing of membranes was not observed, the patient was classified in retrospect as having had ruptured membranes at the time of the initial investigation. The women in this group were thus subdivided into 2 subgroups: Subgroup D - comprising the women whose membranes had been intact at the time of the initial investigation, and subgroup $\mathrm{E}$ - comprising those whose membranes had already been ruptured at the time of the initial investigation. These women were classified according to the length of the latent period: $0-1$, $2-4,5-12,13-24$ or longer than 24 hours. Tab. I represents the composition of the groups.

\subsection{Method of sample collecting and testing}

The patients were placed in the lithotomy position and the cervix visualized through a sterile speculum. A sterile pipet was inserted into the vagina until it reached the posterior fornix, and a drop of fluid was withdrawn by gentle aspiration with a syringe connected to the pipet by a length of a polyethylene tubing. The fluid was then examined as follows: The $\mathrm{pH}$ was determined by wetting an indicator paper (Duotest) $\mathrm{pH}$ range $1-12$ units with a drop of the aspirated fluid. $\mathrm{A} \mathrm{pH} \geqslant 7.0$ was considered to indicate presence of amniotic fluid [5].

For the ferning test a drop of the aspirated fluid was spread on a glass slide, allowed to dry at room temperature and examined under low power $(X 40)$ microscope. The presence of tree-like crystals was considered indicative of the presence of amniotic fluid $[5,14]$.

NBS staining was performed by mixing one drop of the aspirated fluid with a drop of $0.5 \%$ reagent on a microscope slide and examining the preparation under a low power $(X 40)$ microscope. Three orange-brown cells devoid of nuclei, or a cluster of orange-brown cells found in any microscope field was considered positive for the presence of fetal cells [5].

From some of the women in subgroup $A$ and from all the women in subgroup B only one sample from each woman was collected at each examination. However, from each of all the other women, i.e. the rest of the women in subgroup $A$ and all the women in subgroups $\mathrm{C}, \mathrm{D}$, and $\mathrm{E}$, three consecutive samples were collected at each examination. Tab. II represents the distribution of the women and the number of samples collected in the different subgroups.

\section{Results}

A total of 262 women were examined; 575 samples were collected, and 1725 tests were performed (Tab. II). The rate of inaccuracy for the $\mathrm{pH}$, fern and NBS tests are presented in Tabs. III, IV and V.

\subsection{Control group}

Evaluation of the results obtained in women both with intact membranes (subgroup A) and with 
Tab. I. Composition of the groups.

\begin{tabular}{|c|c|c|c|c|c|c|}
\hline $\begin{array}{l}\text { Total } \\
\text { no. of } \\
\text { cases }\end{array}$ & Toxemia & $\begin{array}{l}\text { Gesta- } \\
\text { tional } \\
\text { diabetes }\end{array}$ & $\begin{array}{l}\text { Copious } \\
\text { vaginal } \\
\text { secretions }\end{array}$ & $\begin{array}{l}\text { Meconium } \\
\text { stained } \\
\text { amniotic } \\
\text { fluid }\end{array}$ & $\begin{array}{l}\text { Intra- } \\
\text { uterine } \\
\text { fetal } \\
\text { death }\end{array}$ & $\begin{array}{l}\text { State post } \\
\text { cervical } \\
\text { suture }\end{array}$ \\
\hline
\end{tabular}

\section{Control group}

Diagnosis certain at time of investigation

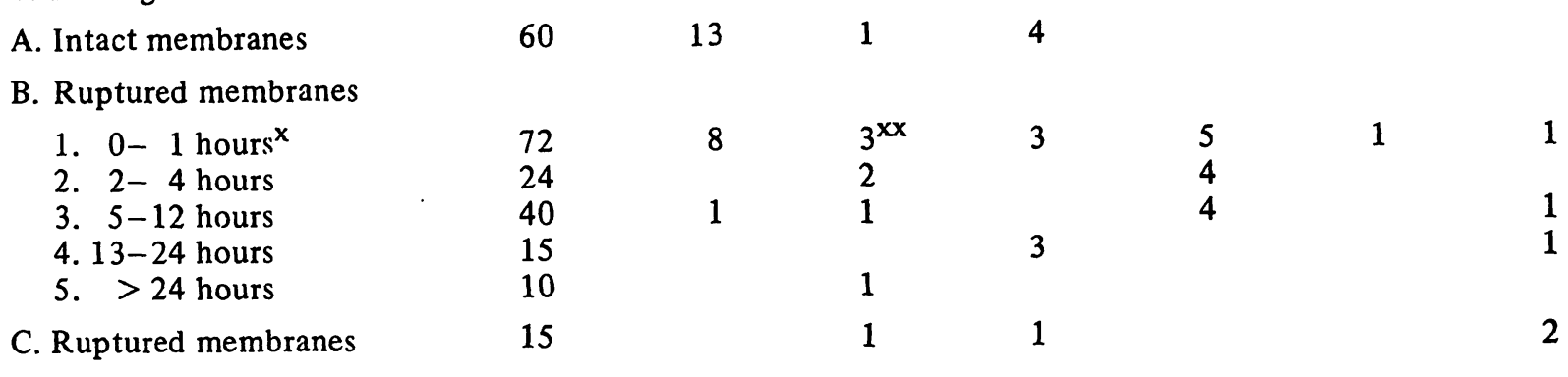

\section{: Test group}

Diagnosis uncertain at time of investigation

D. Intact membranes

8

2

1

4

E. Ruptured membranes

1. 0 - 1 hours $x$

2. 2- 4 hours

3. 5-12 hours

4. 13-24 hours

5. $>24$ hours

$\begin{array}{llll}7 & & 2 & 1 \\ 6 & 2 & 1 & \\ 5 & 1 & & \end{array}$

Total 262

$x$ Time interval elapsed after membrane rupture. $x x$ Two women had overt diabetes.

ruptured membranes (subgroups B, C) revealed that no significant changes occurred when the same woman was examined in different periods of time, or when different women were examined in each group. Thus Tabs. III and IV represent the net results, as follows: In women with intact membranes, high false positive rates were obtained with respect to each test (Tab. III). It was possible to diminish the false positive rates by conducting each test on 3 consecutive samples and regarding 2 or 3 results supporting a single conclusion as the final results. The false positive rates could also be decreased by conducting 2 or 3 tests on each sample. For each women, depending on whether 2 or 3 tests were conducted on 1 sample, 2 or 3 results were obtained. For an accurate diagnosis to be established we required 2 positive results in the former case and 2 or 3 in the latter. However, if 2 or 3 tests were conducted on 3 samples, 6 or 9 results were obtained. If more than two-thirds of the results in any particular woman, i.e. 4 of 6 , or 6 of 9 supported a single conclusion as to whether the tested fluid was cervical mucus or amniotic fluid, the patient was diagnosed as having intact or ruptured membranes. If fewer than two-thirds of the results supported a single conclusion, no diagnosis was made.

It can be seen that by conducting all 3 tests on one fluid sample and preferably on 3 , the false positive rate diminished to 0 (Tab. III).

In women with copious vaginal discharge, higher false positive rates were obtained for each test, but due to the small number of women, no statistical conclusions could be drawn. 
Tab. II. Distribution of the women and the number of samples collected in the different subgroups.

No. of No of samples collected

women from each woman

Total

number of

samples

\section{Control group}

\section{Subgroup $\mathbf{A}^{\mathrm{x}}$}

(Same women examined at different time intervals)

- On admission

- 1-12 hours

$-13-24$ hours

\section{Subgroup B ${ }^{x x}$}

(Different women examined at different time intervals)

- 0 - 1 hours

- 2- 4 hours

- 5-12 hours

- 13-24 hours

$->24$ hours

Subgroup $C^{x x}$

(same women examined at different time intervals)

- 0 - 1 hours

- 2- 4 hours

- 5-12 hours

- 13-24 hours

$->24$ hours

Test group

\section{Subgroup D}

- On admission

\section{Subgroup $E^{x x}$}

(Different women examined at different time intervals)

- 0 - 1 hours

- 2- 4 hours

- 5-12 hours

-13-24 hours

- > 24 hours

Total

$x$ Time interval elapsed after admission.

xx Time interval elapsed after membrane rupture.

In women with ruptured membranes, high false negative rates were obtained with each test. These rates increased progressively and reached values of $50 \%$ when more than 24 hours had elapsed between rupture of the membranes and the investigation. It was possible to reduce the false negative rates by conducting all the 3 tests on 3 consecutive samples (Tab. IV).

In women with meconium stained amniotic fluid, high false negative rates were obtained for each
One from 53, 3 from 7

One from 41, 3 from 7

One from 20, 3 from 7

74

62

41

One from each

One from each

One from each

One from each

One from each

\section{2}

24

40

15

10

Three from each

45

Three from each

45

Three from each $\quad 42$

Three from each

27

Three from each

Three from each

Three from each

21

18

15

62575

test but due to the small number of women no statistical conclusions could be drawn.

\subsection{Test group}

In this group of women the 3 tests were conducted on the 3 samples that were collected and for each woman an ultimate result established, i.e. either correct, equivocal or erroneous diagnosis of PRM. 
Of the 26 women, a correct diagnosis was established in only 16. Either equivocal or erroneous diagnoses were made in the remaining $10(38.5 \%)$ (Tab. V).

Tab. III. False positive responses in subgroup A (control group, intact membranes), in \%.

\begin{tabular}{lcc}
\hline Test method & 1 sample & 3 samples \\
\hline pH & 11 & 8 \\
Ferning & 25 & 18 \\
NBS & 18 & 12 \\
pH + ferning & 8 & 2.5 \\
pH + NBS & 8 & 2.5 \\
Ferning + NBS & 7 & 8 \\
pH + ferning + NBS & 2 & 0 \\
\hline
\end{tabular}

$\mathrm{x}$ Nile blue sulphate staining.

\section{Discussion}

i

PRM is a relatively common event which occurs in $2.7-17 \%$ of all births and is associated with various maternal, fetal and obstetrical complications. The longer the latent period, the more frequently complications occur $[9,13,16]$. In diagnosing PRM, it is often difficult to identify the nature of the fluid in the upper vagina, the main contaminant being cervical mucus. Other contaminating fluids that may be a source of confusion are urine, bath water and vaginal discharge. Associated problems encountered in the diagnosis of PRM are a high rupture of membranes and rupture of the chorionic membrane alone $[1,5,8,12,15]$.

Tab. IV. False negative responses in subgroups B and C (control group, ruptured membranes), in $\%$.

\begin{tabular}{|c|c|c|c|c|c|c|c|c|c|c|}
\hline \multirow[t]{3}{*}{ Test method } & \multicolumn{10}{|c|}{ Time elapsed after rupture of membranes } \\
\hline & \multirow{2}{*}{\multicolumn{2}{|c|}{$\begin{array}{l}0-1 \mathrm{hr} \\
1 \text { samp. }\end{array}$}} & \multicolumn{2}{|c|}{$2-4 \mathrm{hr}$} & \multicolumn{2}{|c|}{$5-12 \mathrm{hr}$} & \multicolumn{2}{|c|}{$13-24 \mathrm{hr}$} & \multicolumn{2}{|c|}{$24 \mathrm{hr}$ or $>24 \mathrm{hr}$} \\
\hline & & & $1 \mathrm{~s}$ & $3 \mathrm{sa}$ & 1 sam & 3 san & $1 \mathrm{sa}$ & $3 s$ & $1 \mathrm{sa}$ & 3 samp. \\
\hline $\mathrm{pH}$ & 9.5 & 7 & 12 & 9 & 12 & 9.5 & 36 & 29 & 50 & 24 \\
\hline Ferning & 20 & 16 & 12 & 9 & 45 & 32 & 54 & 44 & 50 & 18 \\
\hline $\mathrm{NBS}^{\mathrm{x}}$ & 28 & 20 & 25 & 17 & 38 & 21 & 36 & 24 & 66 & 53 \\
\hline $\mathrm{pH}+$ ferning & 5 & 2 & 4 & 3 & 8 & 6 & 27 & 19 & 33 & 12 \\
\hline $\mathrm{pH}+\mathrm{NBS}$ & 3 & 3 & 0 & 0 & 2 & 1 & 9 & 5 & 33 & 12 \\
\hline Ferning + NBS & 8 & 7 & 8 & 6 & 17 & 10 & 18 & 10 & 37 & 14 \\
\hline $\mathrm{pH}+$ ferning $+\mathrm{NBS}$ & 1 & 2 & 0 & 0 & 2.5 & 1 & 9 & 5 & 19 & 10 \\
\hline
\end{tabular}

$\mathrm{x}$ Nile blue sulphate staining

Tab. V. Accuracy of the $\mathrm{pH}$, ferning and nile blue sulphate staining methods in diagnosing rupture of the membranes in the test group.

\begin{tabular}{llll}
\hline Specification & $\begin{array}{l}\text { Correct } \\
\text { diagnosis }\end{array}$ & $\begin{array}{l}\text { No decision } \\
\text { (equivocal) } \\
\text { or } \\
\text { erroneous } \\
\text { diagnosis }\end{array}$ \\
& \multicolumn{3}{l}{ Total } \\
\hline Intact membranes & 5 & 3 & 8 \\
Ruptured membranes & 11 & 7 & 18 \\
\hline
\end{tabular}

Various diagnostic methods are available to the obstetrician dealing with the problem, and these be divided into the following:

1. Clinical evaluation by repeated visual inspection of the cervix, while applying pressure over the uterine fundus.
2. Examination of the fluid present in the posterior fornix for $\mathrm{pH}$, ferning, different staining methods and biochemical parameters $[3-7,11$, 14].

3. Introduction of a color substance by amniocentesis and recovering it from the cervix [2].

Of the above various tests, the most popular are $\mathrm{pH}$, ferning and NBS staining [5]. The accuracy rates of these methods were previously evaluated by retrospective and prospective studies $[5,6,12]$. In the present study it was decided to reevaluate the accuracy of these methods by a prospective study protocol. The results revealed that in each one of the methods, high rates of inaccuracy were encountered which increased progressively when more than one hour has elapsed since the rupture of the membranes, and became unreliable after 24 hours. It was possible to increase the accuracy of 
the tests by conducting all 3 tests concomitantly on 3 fluid samples. Nevertheless, the results that were obtained in the test group were discouraging despite the fact that the above mentioned scheme was applied. In $38.5 \%$ of the patients either erroneous diagnosis or inconclusive information were obtained. It seems that these results, which are inferior to those obtained by clinical examination alone $[5,12]$, reflect the actual inaccuracy of the above methods rather than the inaccuracy rates that were obtained in the control group. It is therefore concluded that the $\mathrm{pH}$, ferning and NBS methods have high inaccuracy rates which increase progressively when more than one hour has elapsed since the rupture of the membranes and will provide no better diagnostic information than that obtained by clinical examination. The results of these tests become unreliable when 24 hours or more have elapsed since the rupture of the membranes.

\section{Summary}

The accuracy rates of 3 diagnostic methods, namely $\mathrm{pH}$ determination, fern test and nile blue sulphate (NBS) staining, in the evaluation of women with prolonged premature rupture of fetal membranes (PRM), were investigated in a prospective study.

Two hundred and sixty-two women, divided into control and test groups, were examined. A total of 1725 tests were performed. The results indicate that these tests have high inaccuracy rates which increase progressively when more than one hour has elapsed since the rupture of the membranes, and become unreliable after 24 hours. It is concluded that in cases of prolonged PRM these tests provide no better diagnostic information than that obtained by clinical evaluation.

Keywords: Fern test, nile blue sulphate staining, $\mathrm{pH}$, pregnancy, premature rupture of membranes.

\section{Zusammenfassung}

Neubewertung von pH-Messung, Farntest und Nilblausulphat-Färbung bei schwangeren Frauen mit vorzeitigem Blasensprung

Die Genauigkeitsrate von drei diagnostischen Methoden, der pH-Messung, dem Farntest und der Nilblausulphat(NBS)Färbung, wurden in einer prospektiven Studie bei Frauen mit vorzeitigem Blasensprung untersucht.

262 Frauen wurden, geteilt in eine Kontroll- und eine Testgruppe, untersucht, und insgesamt wurden 1725 Tests durchgeführt. Die Ergebnisse zeigen, daß diese Tests hohe Ungenauigkeitsraten haben, die immer größer werden, wenn mehr als eine Stunde seit dem Blasensprung vergangen ist. Nach 24 Stunden werden sie unzuverlässig. Wir schließen daraus, daß in Fällen, in denen der vorzeitige Blasensprung schon weiter zurückliegt, diese Tests keine bessere diagnostische Information liefern als die klinische Untersuchung.

Schlüsselworte: Farntest, Nilblạusulphat-Färbung, pH, Schwangerschaft, vorzeitiger Blasensprung.

\section{Résumé}

Réévaluation du $\mathrm{pH}$, des methodes de coloration au sulfate de bleu de Nile et du fern-test, chez les femmes atteintes de rupture prématurée des membranes Les auteurs ont déterminé par une étude prospective la fiabilité de 3 méthodes diagnostiques, la détermination du $\mathrm{pH}$, le fern-test et la coloration au sulfate de bleu de Nile (CBN), chez les femmes présentant une rupture prématurée des membranes (RPM) prolongée.
262 femmes réparties en đeux groupes, témoins et testées, ont été examinées; au total 1725 tests ont été pratiqués. Les résultats montrent que ces tests ont une fiabilité très faible et qui diminue progressivement lorsque le délai entre la rupture et les tests est de plus d'une heure et qui perd toute signification au-delà de 24 heures. Les auteurs concluent que dans les cas de RPM prolongées, ces tests ne procurent pas d'information diagnostique supérieure à l'estimation clinique.

Mots-clés: Coloration au sulfate de bleu de Nile, fern-test, grossesse, $\mathrm{pH}$, rupture prématurée des membranes. 
Bibliography

[1] ABE, T.: The detection of the rupture of fetal membranes with the nitrazine indicator. Amer. J. Obstet. Gynec. 39 (1940) 400

[2] ATLAY, R. D., J. R. SUTHERT: Premature rupture of the fetal membranes confirmed by intraamniotic injection of dye (Evans blue T-1824). Amer. J. Obstet. Gynec. 108 (1970) 993

[3] AVERETTE, H. E., B. C. HOPMAN, J. H. FERGU. SON: Cytodiagnosis of ruptured fetal membranes. Amer. J. Obstet. Gynec. 87 (1963) 226

[4] BROSENS, I., H. GORDON: The cytological diagnosis of ruptured membranes using nile blue sulphate staining. J. Obstet. Gynaec. Brit. Cwlth. 72 (1965) 342

[5] FRIEDMAN, M. L., T. W. MCELIN: Diagnosis of ruptured fetal membranes. Clinical study and review of the literature. Amer. J. Obstet. Gynec. 104 (1969) 544

[6] GALL, S. A., W. N. SPELLACY: Cytologic diagnosis of ruptured membranes. Obstet. and Gynec. 24 (1964) 732

[7] GORODSKI, I. G., M. PAZ, V. INSLER, J. FISHEL: Diagnosis of rupture of the fetal membranes by glucose and fructose measurements. Obstet. and Gynec. 53 (1979) 611

[8] KOVACKS, D.: Crystallization test for the diagnosis of ruptured membranes. Amer. J. Obstet. Gynec. 83 (1962) 1257
$: 1$

[9] LANIER, L. R. Jr., R. W. SCARBROUGH Jr., D. W. FILLINGIM, R. E. BAKER Jr.: Incidence of maternal and fetal complications associated with rupture of the membranes before onset of labor. Amer. J. Obstet. Gynec. 93 (1965) 398

[10] LEADING ARTICLE: Premature rupture of membranes and maternal death. Brit. Med. J. 4 (1967) 504

[11] POLISHUK, W. Z., S. KOHANE, N. WIZNITZER: Premature rupture of membranes in different ethnic groups. Isr. J. Med. Sci. 1 (1965) 450

[12] REID, D. E., C. D. CHRISTIAN: Controversy in Obstetrics and Gynecology. Part II. Saunders, Philadelphia 1974

[13] SACKS, M., T. H. BAKER: Spontaneous premature rupture of membranes: A prospective study. Amer. J. Obstet. Gynec. 97 (1967) 888

[14] TRICOMI, V., J. E. HALL, A. BITTAR, D. CHAMBERS: Arborization test for the detection of ruptured fetal membranes. Clinical evaluation. Obstet. Gynec. 27 (1966) 275

[15] UlleRY, J. C. E. H. SHABANAH: The cervicalmucus smear during pregnancy and the fate of conception. Obstet. and Gynec. 10 (1957) 233

[16] WILSON, M. G., D. H. ARMSTRONG, R. C. NEL SON: Prolonged rupture of fetal membranes. Am. J. Dis. Childh. 107 (1964) 138

Received February 12, 1982. Revised April 2, 1982. Accepted August 27, 1982.

Dr. I. G. Gorodeski

Department of Obstetrics and Gynecology "B" Meir Hospital, Sapir Medical Center

Kfar-Saba, Israel 